\title{
Salinity effect on growth and toxin production of four tropical Alexandrium species (Dinophyceae)
}

\author{
Po-Teen Lim ${ }^{\mathrm{a}, \mathrm{b}, *}$, Takehiko Ogata ${ }^{\mathrm{a}}$ \\ ${ }^{a}$ School of Fisheries Science, Kitasato University, Sanriku, Ofunato, Iwate 022-0101, Japan \\ ${ }^{\mathrm{b}}$ Faculty of Resource Science and Technology, Universiti Malaysia Sarawak, Kuching, Sarawak 94300, Malaysia
}

Received 9 August 2004; revised 27 December 2004; accepted 10 January 2005

\begin{abstract}
Four tropical PSP toxins-producing dinoflagellates, Alexandrium minutum, Alexandrium tamiyavanichii, Alexandrium tamarense and Alexandrium peruvianum from Malaysian waters were studied to investigate the influences of salinity on growth and toxin production. Experiments were conducted on constant temperature $25^{\circ} \mathrm{C}, 140 \mu \mathrm{E} \mathrm{mol} \mathrm{m}{ }^{-2} \mathrm{~s}^{-1}$ and under 14:10 light:dark photo-cycle with salinity ranged from 2 to 30 psu. The PSP-toxin congeners, GTX 1-6, STX, dcSTX, NEO and $\mathrm{C} 1-\mathrm{C} 2$ were analysed by high performance liquid chromatography. Salinity tolerance of the four species in decreasing order is A. minutum $>$ A. peruvianum $>$ A. tamarense $>$ A. tamiyavanichii. Specific growth rates and maximum densities varied among these species with $A$. minutum recorded as the highest, 0.5 day $^{-1}$ and $6 \times 10^{4}$ cells mL ${ }^{-1}$. Toxin content decreased with elevated salinities in A. minutum, the highest toxin content was about $12 \mathrm{fmole} \mathrm{cell}^{-1}$ at $5 \mathrm{psu}$. In A. tamiyavanichii, toxin content peaked at optimal growth salinity (20 and $25 \mathrm{psu}$ ). Toxin content of A. tamarense, somehow peaked at sub-optimal growth salinity (15 and $30 \mathrm{psu}$ ). Results of this study implied that salinity fluctuation not only influenced the growth physiology but also toxin production of these species.
\end{abstract}

(C) 2005 Elsevier Ltd. All rights reserved.

Keywords: Alexandrium minutum; A. tamiyavanichii; A. tamarense; A. peruvianum; Paralytic shellfish poisoning toxins; Salinity tolerance

\section{Introduction}

Dinoflagellates from the genus Alexandrium have been well known as producers for the potent neurotoxins that cause paralytic shellfish poisoning (PSP) in many coastal countries throughout the world (Anderson et al., 1994; Halegraeff et al., 1995). Blooms of Alexandrium and

Abbreviations: psu, pratical salinity unit; PSP toxins, paralytic shellfish poisoning toxins; GTXs, gonyautoxins; STXs, saxitoxins; dcSTX, decarbomoyl-saxitoxin; NEO, neosaxitoxin; C toxins, $\mathrm{N}$ sulfo-carbamoyl-toxins.

* Corresponding author. Address: School of Fisheries Science, Kitasato University, Sanriku, Ofunato, Iwate 022-0101, Japan. Tel.: +81 19244 2121; fax: +81 192442125 .

E-mail addresses: lim@st.kitasato-u.ac.jp (P.-T. Lim), ptlim@frst.unimas.my (P.-T. Lim). outbreak of poisoning cases have caused serious economic losses in the fishery industries of the affected countries. Public health concern arose with increasing poisoning cases due to the consumption of contaminated bivalves. This has been particularly pronounced in countries where seafood is the main source of protein. Malaysia is not an exception from this menace. Before 1990s, Pyrodinium bahamense is the only PSP causative organism in Malaysian waters with blooms and PSP outbreaks confined to Sabah. The perception changed with the increased in number of toxic Alexandrium species found as well as the PSP cases reported in Peninsula Malaysia (Usup et al., 2002; Lim et al., 2002). Five species of Alexandrium have been identified. Out of these species, Alexandrium tamiyavanichii and Alexandrium minutum were reported as toxic (Usup et al., 2002). Two additional Alexandrium species, namely Alexandrium taylori and Alexandrium peruvianum were later found in 